\title{
Water Quality Parameters: Statistical Point of View
}

\author{
Taiwo Abideen Lasisi ${ }^{1} \quad$ Olukunmi Olatunji Akanni ${ }^{2}$ \\ 1.Department of Mathematics and Statistics, The Polytechnic Ibadan, Nigeria \\ 2.Department of Public Health, Lead City University, Ibadan, Nigeria
}

\begin{abstract}
Water is a fundamental basic need for sustaining human and economic activities. Availability of water in the desired quantity and quality, at the right time and place has been the key to the survival of all civilizations. This paper assesses the water quality of the Eleyele dam in Oyo State, Nigeria using statistical techniques so as to ensure proper monitoring and controlling of discharged water to the community. Water samples were collected daily from the Eleyele dam using stratified sampling techniques from four different sampling points on the dam for a period of three months for physicochemical analysis. The time series plot shows irregular variation in the behaviour of the water quality parameters as there is presence of extreme values in the parameters. Colour, turbidity, $\mathrm{pH}$, dissolve oxygen, alkalinity, total hardness, chloride, silica, chlorine ranged between 25.969 $\pm 36.034 \mathrm{TCU}$, $6.032 \pm 7.355 \mathrm{NTU}, \quad 6.774 \pm 0.363, \quad 5.913 \pm 2.397 \mathrm{mg} / \mathrm{l}, \quad 83.380 \pm 35.794 \mathrm{mg} / \mathrm{l}, \quad 93.016 \pm 15.197 \mathrm{mg} / \mathrm{l}$, $32.944 \pm 8.796 \mathrm{mg} / \mathrm{l}, \quad 5.759 \pm 2.205 \mathrm{mg} / 1$ and $3.786 \pm 1.822 \mathrm{mg} / 1$ respectively. Total hardness significantly correlated with alkalinity $(\mathrm{r}=0.429, \mathrm{P}<0.05), \mathrm{pH}(\mathrm{r}=0.404, \mathrm{P}<0.05)$ and silica $(\mathrm{r}=0.324, \mathrm{P}<$ $0.05)$. Turbidity significantly correlated with alkalinity $(\mathrm{r}=0.332, \mathrm{P}<0.05)$ and $\mathrm{pH}(\mathrm{r}=0.370, \mathrm{P}<$ $0.05)$ while chlorine significantly correlated with alkalinity $(\mathrm{r}=0.335, \mathrm{P}<0.05)$. Alkalinity significantly correlated with $\mathrm{pH}(\mathrm{r}=0.548, \mathrm{P}<0.05)$ and colour $(\mathrm{r}=0.515, \mathrm{P}<0.05)$. Dissolved oxygen obtained may not be favorable for the snail host. The alkalinity, turbidity, colour and silica are above WHO guidelines for drinking water quality. The attention of governments and stake-holders must be drawn to the water quality of the dam as it may have effect on the public health and increases mortality rate due to water borne and associated diseases
\end{abstract}

Keywords: Physico-chemical, Public health, Mortality, Water quality, Dam, Snail

DOI: $10.7176 / \mathrm{JNSR} / 11-18-06$

Publication date:September $30^{\text {th }} 2020$

\subsection{Introduction}

Access to safe drinking water and sanitation is a global concern. However, developing countries, like Nigeria, have suffered from a lack of access to safe drinking water from improved sources and to adequate sanitation services (WHO, 2006). As a result, people are still dependent on unprotected water sources such as rivers, streams, springs and hand dug wells. Since these sources are open, they are highly susceptible to flood and birds, animals and human contamination. In addition, most sources are found near gullies where open field defecation is common and flood-washed wastes affect the quality of water (Meseret, 2012). Safe water is fundamental to better health, alleviating poverty and community development. The Covenant on Economic, Social and Cultural Rights (CESCR) explicitly recognized water as a fundamental human right in November 2002 and the countries which ratified the International CESCR are compelled to ensure everyone has access to adequate and safe supply of drinking water. The lack of access to safe water and adequate sanitation is at the core of the main symptoms and causes of world poverty, reinforcing the cycle of poverty and incapacity that keeps people trapped and slows the development of societies. Mathew (2005) mentioned that inadequate access to safe water can cause people's health to suffer, especially children, ranging from reduced growth and life expectancy to critical bouts of diseases, often leading to death. The WHO (2006) estimates that $88 \%$ of diarrhea disease is attributed to unsafe water supply, inadequate sanitation and poor hygiene, resulting in the deaths of more than two million people every year. The availability of plentiful and safe water for domestic use and adequate sanitation have long been known to be fundamental to the development process (Gadgil, 1998) and promote the reduction of poverty. Currently, half the populations do not have access to safe water (UNDP, 2006). This is a driving force behind achieving the globally recognized Sustainable Development Goals i.e. Ensure availability and sustainable management of water and sanitation for all (Goal 6). It is common that people who are most vulnerable to water-borne diseases are those who use polluted drinking water sources. UNICEF (2010) discovered that; in the world, 884 million people use unimproved drinking water sources in 2010, and in 2015 estimates about 672 million people will still using unimproved drinking water sources. The WHO (2000) reported that polluted drinking water causes about 1.8 million peoples' death resulting from diarrheal diseases annually worldwide and seventy five percent of all diseases in developing countries arise from polluted drinking water. The lack of access to water also limits sanitation and hygiene practices in many households because of the priority given for drinking and cooking purposes. Water quality concerns are often the most important component for measuring access to improved water sources. 
Acceptable quality shows the safety of drinking water in terms of its physical, chemical and bacteriological parameters (WHO, 2004). The need to the challenges of poor water quality, prevalence of water borne diseases and bring about the realization of the SDGs goals in order to make our world a better place to leave is nonnegotiable. Meseret (2012) mentioned that lack of access to safe and clean water is locked in the heart of the poverty. Even though the issue of water is observed as a general problem for both the urban and the rural population, women bear the greatest burden because of their social gender roles including collecting water for their households (Rose, 2009). Because of their task of water provision at the households, women and children suffer from disease, have limited participation in education, and both income generating activities and engagement in cultural and political issues are often compromised. Crow (2001) noted that most of the children miss the opportunity of attending school, while women spend $10-50 \%$ of their daytime fetching water from polluted water points, losing time on productive activities. ADF (2005) mentioned that one third of women in some of the regions spent more than two hours for each water collection trip. This fact is aggravated by the poor supply efficiency, resulting from bad condition, which cannot satisfy the entire populations from different villages sharing the same water source and increased queuing time is common during the dry seasons (Admasu et al., 2002). Improving the water supply coverage and quality has a number of consequences in addition to the fact that investigating the socioeconomic and other factors affecting household water consumption patterns provides guidance for policy makers and those in various agencies implementing projects. In order to achieve the SDGs of access to improved water sources is better to incorporate each element to understand and recommend the major factors which hinder the vision of the long term programs for the provision of safe or quality water and sanitation services. Therefore there is need to rise to the challenges of providing access to good and safe drinking water because of hazardous effect poise by unsafe and polluted water, reduce the problem faced by women in providing quality water for their households, reduce the diseases associated with unsafe water and bring about the realization of the SDGs goals.

\subsection{Materials and Methods \\ 2.1 Study Area}

The study was conducted on Eleyele dam which is located in north-eastern part of Ibadan, south-western Nigeria within longitude $080026 ! 00 ! ! \mathrm{N}$ and 08 !028000!!N and Latitude $040052 ! 00 ! ! \mathrm{E}$ and 0040055 ! 00 !!E. The study site is surrounded by Eleyele community toward the south, Apete community toward the east and Awotan community toward the north. The water from the dam serves as a very important source of domestic water supply, transportation, farming, fishing and recreation to the community and people of Oyo State.

\subsection{Sampling Techniques}

Water samples were collected daily from the dam using stratified sampling techniques from four different sampling points on the dam for a period of three months. The coordinates of these points are Point A- Latitude 07026!22.7!! N and Longitude 003052!26.8!!E; Point B- Latitude 07026!22.9!!N and Longitude 003!52!29.7!!E; Point C- Latitude $07026 ! 32.4$ !!N and Longitude 003052!32.1!!E; Point D- Latitude 07026!31.4!!N and Longitude 003052!38.6!!E.

\subsubsection{Parameters}

The iphysical and chemical and bacteriological parameters of the water were measured which include Colour, $\mathrm{PH}$, Total Dissolved Oxygen, Total Hardness, Turbidity, Chloride, Total Alkalinity, Silica, Chlorine

\subsection{Statistical Analysis and Model}

The quality control check was carried out on the parameters using control charts, descriptive analysis and correlation matrix. SPSS version 20 and R version 3.5.0 were used to analyze the parameters with $P<0.05$ to measure the significance of the parameters.

The parameters sampled daily for period of three months is given by

$$
x=f(t)
$$

Where $x$ is the parameters and $t$ is the sampling period.

The icorrelation coefficient for the parameter is given as

$$
r_{i j}=\frac{n \Sigma X_{i} X_{j}-\Sigma X_{i} \Sigma X_{j}}{\sqrt{\left[n \Sigma X_{i}^{2}-\left(\Sigma X_{\mathrm{i}}\right)^{2}\right]\left[n \Sigma X_{j}^{2}-\left(\Sigma \mathrm{X}_{\mathrm{j}}\right)^{2}\right]}}
$$

The icorrelation matrix for the parameters is obtained as 


$$
r_{i j}=\left[\begin{array}{ccccc}
1 & r_{12} & r_{13} & \ldots & r_{1 j} \\
r_{21} & 1 & r_{23} & \ldots & r_{2 j} \\
r_{31} & r_{32} & 1 & \ldots & r_{3 j} \\
\vdots & \vdots & \vdots & \ddots & \vdots \\
r_{i 1} & r_{i 2} & r_{i 3} & \ldots & r_{i j}
\end{array}\right]
$$

\subsection{Results and Discussion}

Physico-chemical parameters of water are difficult to gather because governments, and policy and decision makers are yet to appreciate the importance of data to development especially in developing country. The expensive nature of data collection and analysis of water quality parameters data and the stringent law put in place by government in assessing the dams is of major concern to the researchers. The results showed irregular variation in the behaviour of the water quality parameters (Figures 2-10), as some extreme values were noticed in some parameters like colour, turbidity, DO, total hardness, chloride and chlorine (Figure 1). Table 2 revealed that Total hardness significantly correlated with alkalinity $(\mathrm{r}=0.429, \mathrm{P}<0.05), \mathrm{pH}(\mathrm{r}=0.404, \mathrm{P}<0.05)$ and silica $(\mathrm{r}=0.324$, $\mathrm{P}<0.05)$. Turbidity significantly correlated with alkalinity $(\mathrm{r}=0.332, \mathrm{P}<0.05)$ and $\mathrm{pH}(\mathrm{r}=0.370, \mathrm{P}<0.05)$ while chlorine significantly correlated with alkalinity $(\mathrm{r}=0.335, \mathrm{P}<0.05)$. Alkalinity significantly correlated with $\mathrm{pH}$ $(\mathrm{r}=0.548, \mathrm{P}<0.05)$ and colour $(\mathrm{r}=0.515, \mathrm{P}<0.05)$. A low $\mathrm{pH}$ value is hazardous to freshwater snails, which result into coagulation of the snails' exposed skin surface, affecting respiration and movement and consequently lead to their death (Jordan and Webbe, 1982). The $\mathrm{pH}$ range observed during the study was 6.0-7.50 with mean 6.77 and standard deviation of 0.36 . The $\mathrm{pH}$ during of water samples ranged from slightly acidic value of 6.50 to basic 8.50 (Sharma et al., 2013). The $\mathrm{pH}$ range measured was in consonance to the $\mathrm{pH}$ obtained by Hyeladi and Nwagilari (2014) during their study on Alau dam in Maiduguri, Borno State, Nigeria. However, this range is slightly higher than those recorded by Ewa et al., (2011) in Omoku Creek, River State that recorded pH range of 5.4-6.8 during the study because of high salinity recorded at Omoku Creek or as a result of deposition of organic matter into water from run-off or partial decomposition of organic matter by bacteria and fungi that produces various organic acids that are capable of lowering the $\mathrm{pH}$.

The dissolved oxygen content of water is influenced by the source, raw water temperature, treatment and chemical or biological processes taking place in the distribution system. Depletion of dissolved oxygen in water supplies can encourage the microbial reduction of nitrate to nitrite and sulfate to sulfide. It can also cause an increase in the concentration of ferrous iron in solution, with subsequent discoloration at the tap when the water is aerated, very high levels of dissolved oxygen may exacerbate corrosion of metal pipes (WHO, 2017). Snails requires oxygen for their metabolic activities (WHO, 1965). The dissolved oxygen (DO) range of $0.8-11.80 \mathrm{mg} / \mathrm{L}$ was recorded during this study. This implies that the amount of dissolved oxygen may not be favorable for the snail host. The recorded dissolve oxygen is in tune with Harman and Berg (1971) which obtained dissolve oxygen for fresh water $0.40-16.00 \mathrm{mg} / \mathrm{L}$. Owojori et al., (2006) that recorded dissolve oxygen range of $2.8-14.2 \mathrm{mg} / \mathrm{L}$ at Opa reservoir, above Hussein et al., (2011) of dissolve oxygen range of 2.4-8.6 mg/L obtained at research farm ponds in Obafemi Awolowo University Ile-Ife, above Yirenya-Tawiah et al., (2011) of dissolve oxygen 0.9-7.3 $\mathrm{mg} / \mathrm{L}$. The dissolve oxygen of range of 4.4-22.0 mg/L in Manhasan stream, Jammu is extremely high from the dissolve oxygen range obtain from this study (Sharma et al., 2013)

Alkalinity (carbonate and bicarbonate) and calcium (hardness) affect corrosion rates. Alkalinity and calcium management also contribute to the stability of water and control its aggressiveness to pipes and appliances. Failure to minimize corrosion can result in the contamination of drinking-water and in adverse effects on its taste and appearance. The major water quality factors that determine whether the precipitate forms a protective scale are $\mathrm{pH}$ and alkalinity (WHO, 2017). The alkalinity range of $14-158 \mathrm{mg} / \mathrm{L}$ with mean 83.380 and standard deviation 35.794 was recorded during this study, this value extremely above the WHO guidelines for drinking water quality (WHO, 2017). The alkalinity range recorded is greater than alkalinity range recorded by Owojori et al., (2006) during the study of Opa reservoir and farm ponds in Obafemi Awolowo University, Ile-Ife, greater than alkalinity recorded by Oyakhilome et al., (2012), by Adefemi et al., (2007) at Ero and Egbe dam in Ondo State and Hyeladi and Nwagilari (2014) at Owena multi-purpose dam, Ondo State, Nigeria, by Oloyede et al., (2016) during his study on Eleyele dam.

High levels of turbidity can protect microorganisms from the effects of disinfection, stimulate the growth of bacteria and give rise to a significant chlorine demand. Sporadic high turbidity in source water can overwhelm treatment processes, allowing enteric pathogens into treated water and the distribution system. Water treatment systems may need to be upgraded and obtain greater storage capacity to be able to cope with greater microbial, turbidity and chemical loadings. Disinfection, maintaining an adequate disinfectant residual and, where necessary, pretreatment to reduce turbidity to as low as feasible in order to ensure the efficiency of disinfection are essential components in ensuring a safe drinking-water supply. At high levels, turbidity can lead to staining of materials, fittings and clothes exposed during washing, in addition to interfering with the effectiveness of treatment processes (WHO, 2017). The turbidity range of 0.00-44.0 NTU with mean 6.03 and standard deviation 7.36 was recorded 
during this study, this value extremely above the WHO guidelines for drinking water quality (WHO, 2017).

Hardness of water is of major public concern in many parts of the world as the incidences of cardiovascular disorders such arteriosclerosis have been correlated with the hardness of the water (Masironi et al., 1972). Hardness caused by calcium and magnesium is usually indicated by precipitation of soap scum and the need for excess use of soap to achieve cleaning. Consumers are likely to notice changes in hardness. Public acceptability of the degree of hardness of water may vary considerably from one community to another. Depending on the interaction of other factors, such as $\mathrm{pH}$ and alkalinity, water with a hardness above approximately $200 \mathrm{mg} / \mathrm{l}$ may cause scale deposition in the treatment works, distribution system and pipework and tanks within buildings. It will also result in high soap consumption and subsequent "scum" formation. On heating, hard waters form deposits of calcium carbonate scale. Soft water, but not necessarily cation exchange softened water, with a hardness of less than 100 $\mathrm{mg} / \mathrm{l}$, may, in contrast, have a low buffering capacity and so be more corrosive for water pipes (WHO,2017). The total hardness range of 40-134.00 mg/L with mean 93.01 and standard deviation 15.19 was recorded in Eleyele dam. The values recorded from the dam were within the slightly hard classification (EPA, 2001). This range agrees with the Hussein et al., (2011) that recorded total hardness value range of 79.9-437.8 mg/L at Qena Governorate, Upper Egypt and does not agree with Adefemi et al., (2007) and Hyeladi and Nwagilari (2014)

High concentrations of chloride give a salty taste to water and beverages. Taste thresholds for the chloride anion depend on the associated cation and are in the range of 200-300 mg/l for sodium, potassium and calcium chloride. Concentrations in excess of $250 \mathrm{mg} / \mathrm{l}$ are increasingly likely to be detected by taste, but some consumers may become accustomed to low levels of chloride induced taste. The chloride range of $15-90.50 \mathrm{mg} / \mathrm{L}$ with mean 32.94 and standard deviation 8.79 was recorded in Eleyele dam as this is within threshold limit of WHO guidelines for drinking water quality (WHO, 2017).

Drinking-water should ideally have no visible colour. Colour in drinking-water is usually due to the presence of coloured organic matter (primarily humic and fulvic acids) associated with the humus fraction of soil. Colour is also strongly influenced by the presence of iron and other metals, either as natural impurities or as corrosion products. It may also result from the contamination of the water source with industrial effluents and may be the first indication of a hazardous situation. The colour range of 5-140 TCU with mean 25.97 and standard deviation 36.03 was recorded in Eleyele dam as this is above threshold limit of WHO guidelines for drinking water quality (WHO, 2017).

\begin{tabular}{lllll}
\hline Parameters & Mean \pm SD & Minimum & Maximum & WHO Guidelines (2017) \\
\hline COLOUR & $25.969 \pm 36.034$ & 5.00 & 140.00 & 15 \\
TURBIDITY & $6.032 \pm 7.355$ & 0.00 & 44.80 & 5 \\
PH & $6.774 \pm 0.363$ & 6.00 & 7.50 & $6.5-8.5$ \\
DO & $5.913 \pm 2.397$ & .80 & 11.80 & $5-9.5$ \\
ALKALINITY & $83.380 \pm 35.794$ & 14.00 & 158.00 & 50 \\
TOTALHARD & $93.016 \pm 15.197$ & 40.00 & 134.00 & 500 \\
CHLORIDE & $32.944 \pm 8.796$ & 15.00 & 90.50 & 250 \\
SILICA & $5.759 \pm 2.205$ & 4.00 & 10.00 & $0.5-1.0$ \\
CHLORINE & $3.786 \pm 1.822$ & .46 & 9.78 & 5 \\
\hline
\end{tabular}

Table 1: Descriptive Statistics of physico-chemical parameters of Eleyele Dam.

\begin{tabular}{|c|c|c|c|c|c|c|c|c|c|}
\hline Parameters & COLOUR & TURBIDITY & $\mathrm{PH}$ & DO & ALKALINITY & TOTALHARD & CHLORIDE & SILICA & CHLORINE \\
\hline COLOUR & 1 & & & & & & & & \\
\hline TURBIDITY & $.597^{* *}$ & 1 & & & & & & & \\
\hline PH & $407^{* *}$ & $.370^{* *}$ & 1 & & & & & & \\
\hline DO & $-.344^{* *}$ & -.160 & -.012 & 1 & & & & & \\
\hline ALKALINITY & $.515^{* *}$ & $.332^{* *}$ & $.548^{* *}$ & .013 & 1 & & & & \\
\hline TOTALHARD & .087 & .084 & $.404^{* *}$ & .161 & $.429^{* *}$ & 1 & & & \\
\hline CHLORIDE & -.091 & .011 & -.111 & .065 & $-.193^{* *}$ & $-.182^{* *}$ & 1 & & \\
\hline SILICA & -.043 & -.098 & .155 & .114 & .062 & $.324^{* *}$ & -.186 & 1 & \\
\hline CHLORINE & -.058 & .147 & .102 & -.174 & $.335^{* *}$ & .087 & .012 & -.376 & 1 \\
\hline
\end{tabular}

** Correlation is significant at the 0.05 level.

Table 2: Correlation matrix of physico-chemical parameters of Eleyele Dam 

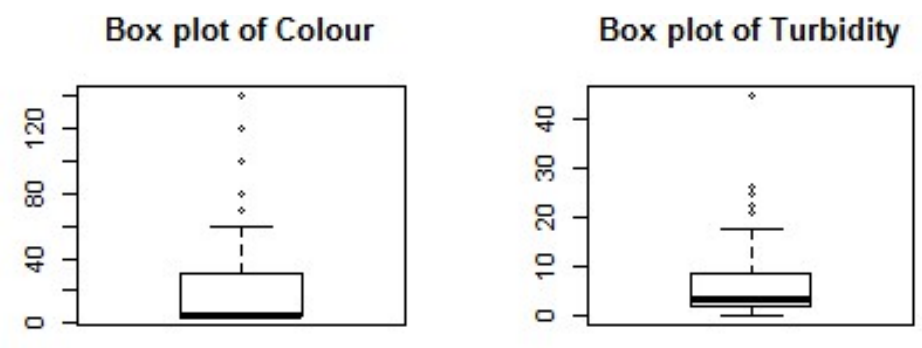

\section{Box plot of $\mathrm{PH}$}

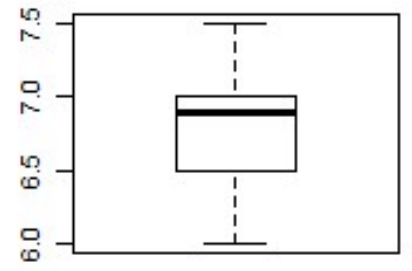

Box plot of DO

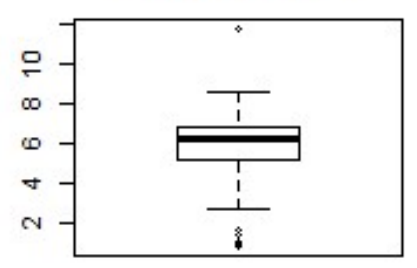

Box plot of Alkalinity

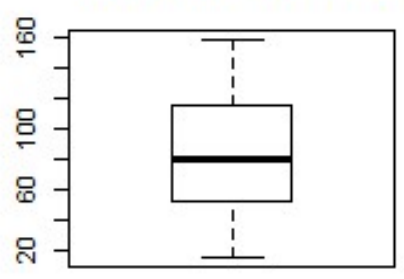

\section{Box plot of Total Hardness}

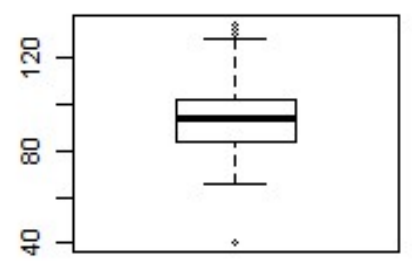

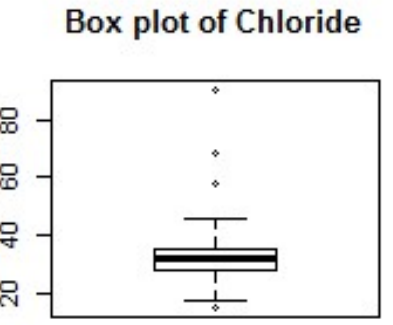

Box plot of Silica

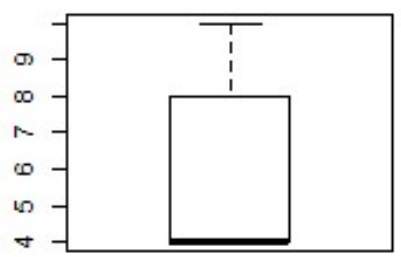

Box plot of Chlorine

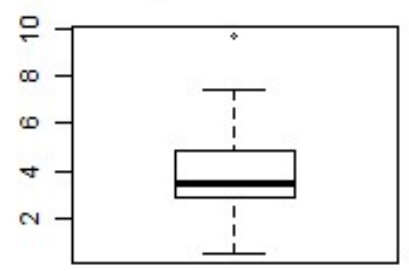

Figure 1:Box plots of physico-chemical parameters of Eleyele Dam

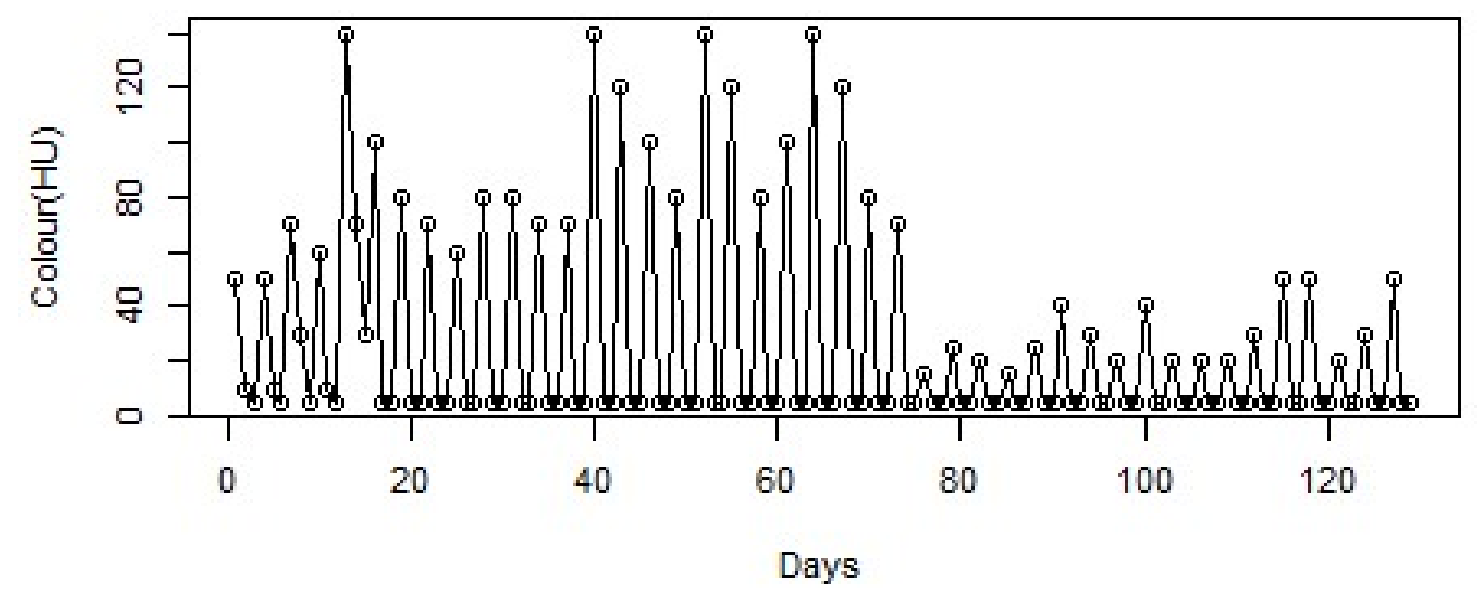

Figure 2: Daily Irregular Time plot of Colour from Eleyele Dam 


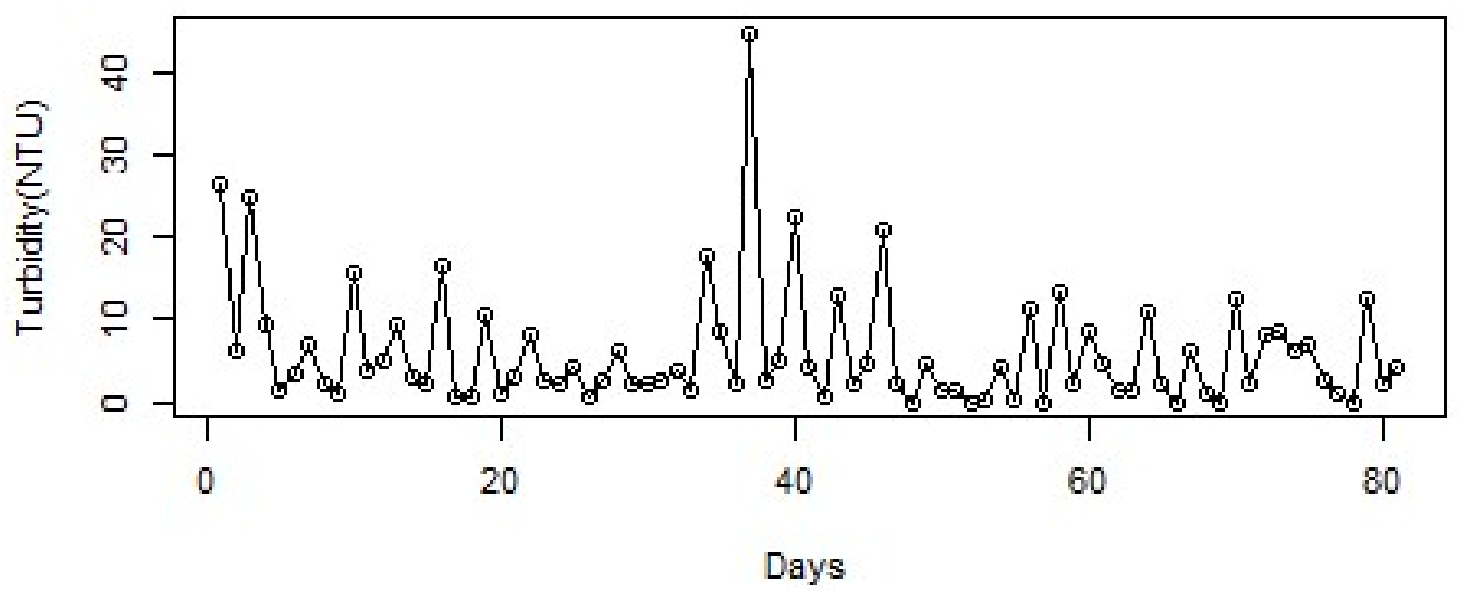

Figure 3: Daily Irregular Time plot of Turbidity from Eleyele Dam

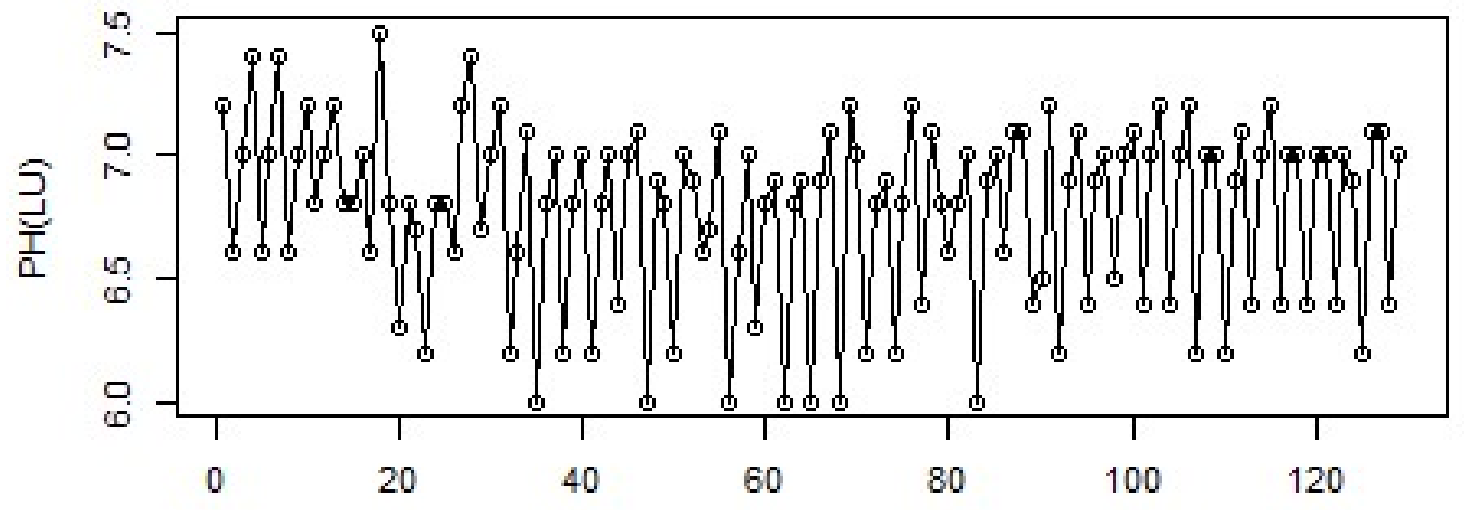

Days

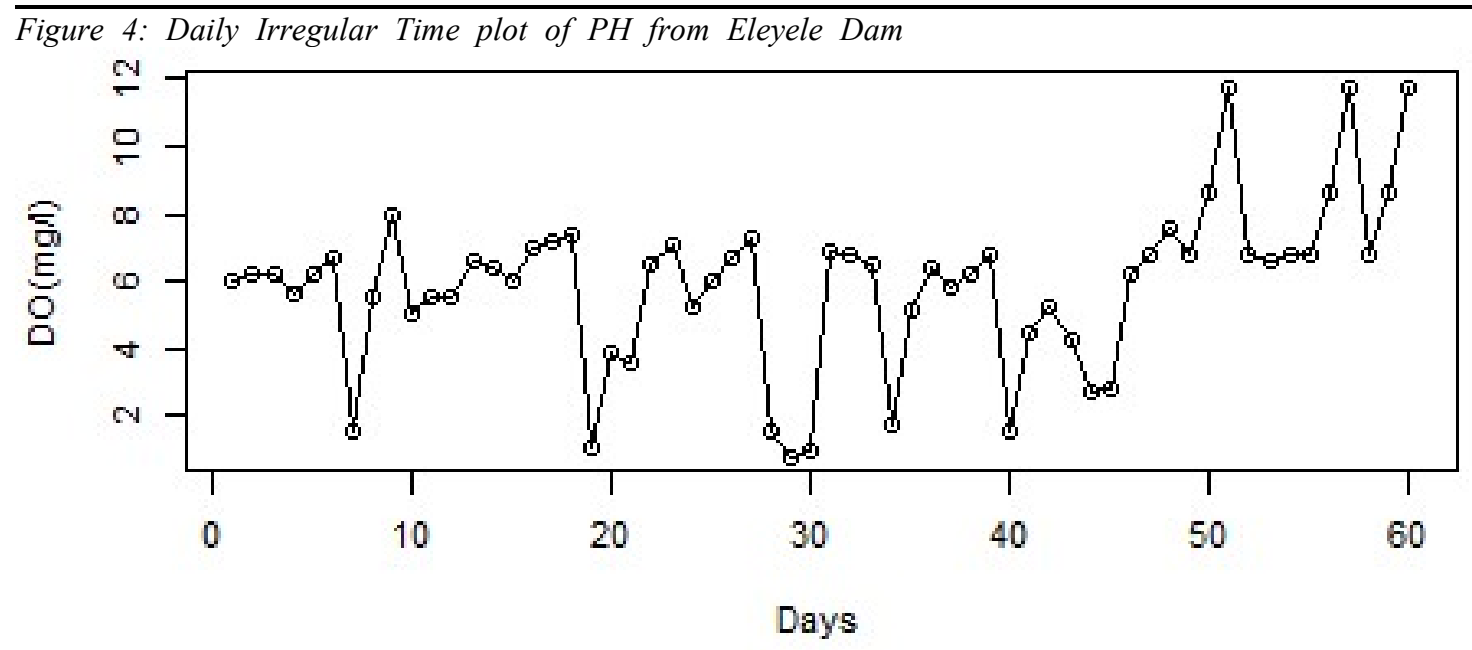

Figure 5: Daily Irregular Time plot of DO from Eleyele Dam 


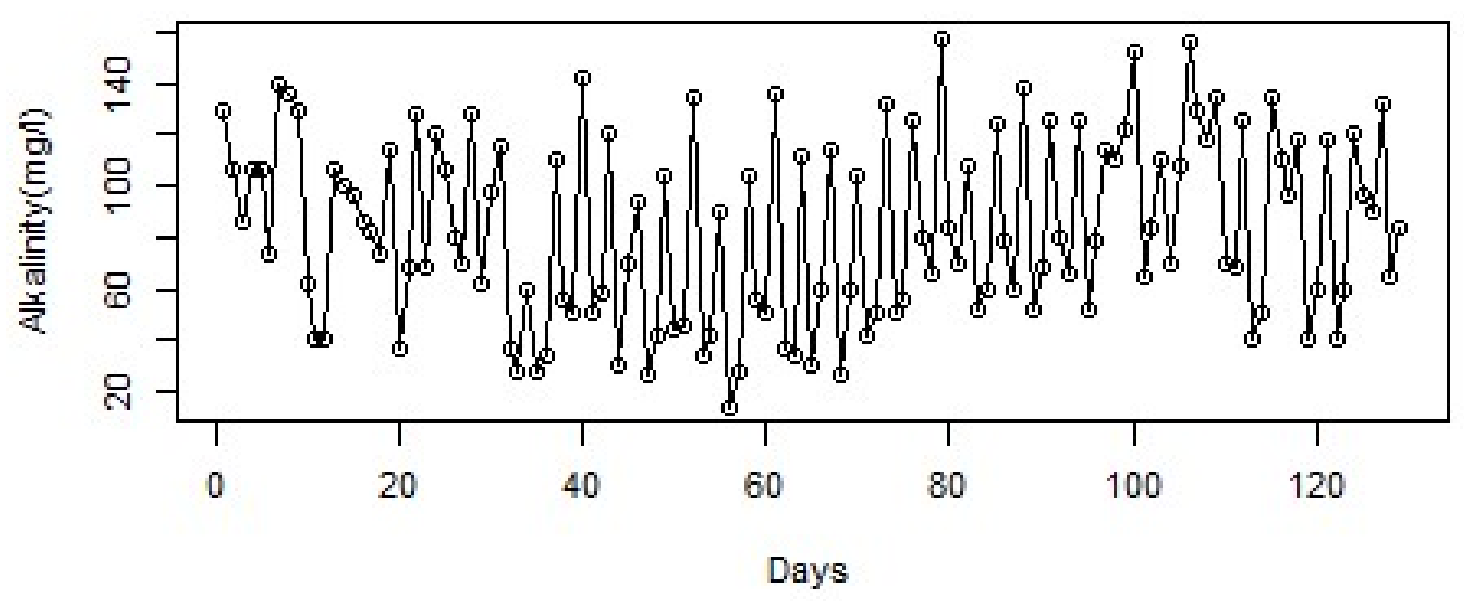

Figure 6: Daily Irregular Time plot of Alkalinity from Eleyele Dam

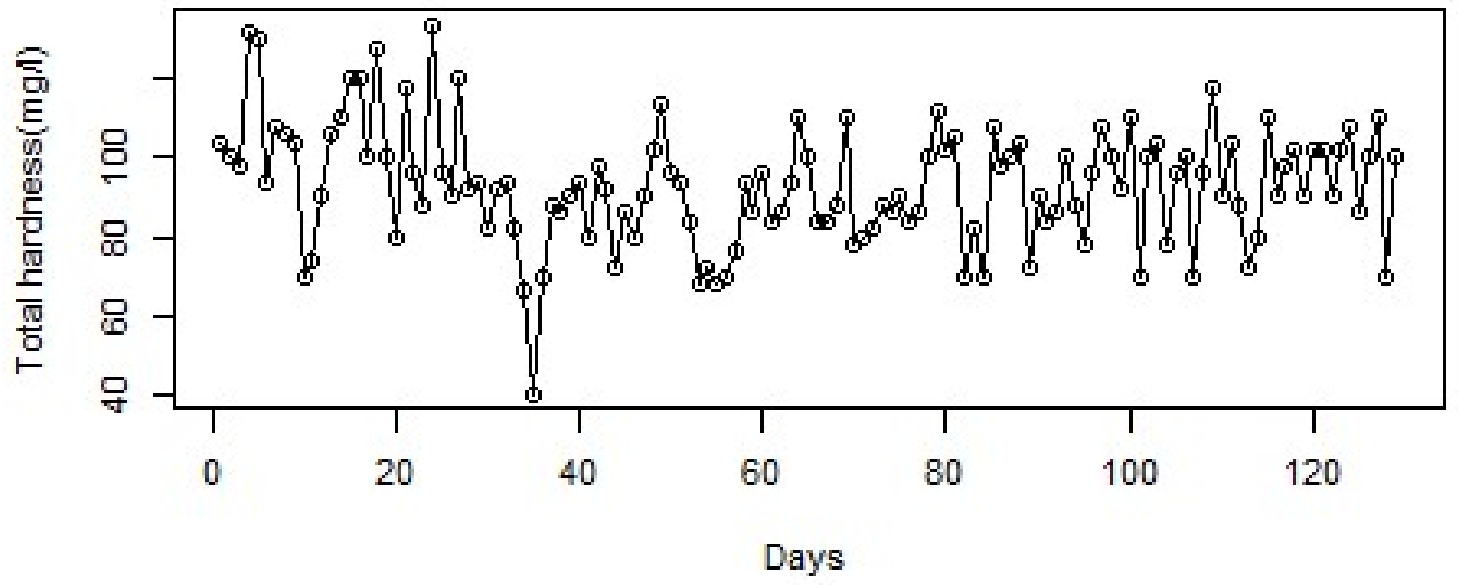

Figure 7: Daily Irregular Time plot of Total Hardness from Eleyele Dam

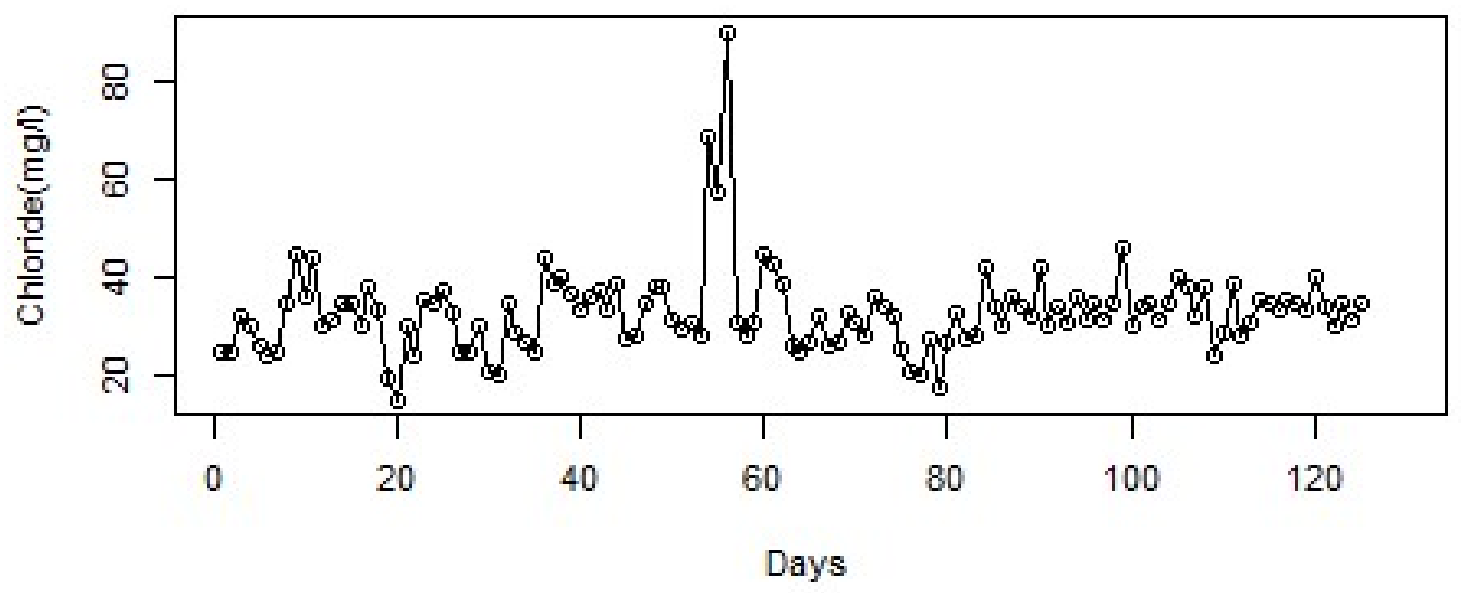

Figure 8: Daily Irregular Time plot of Chloride from Eleyele Dam 


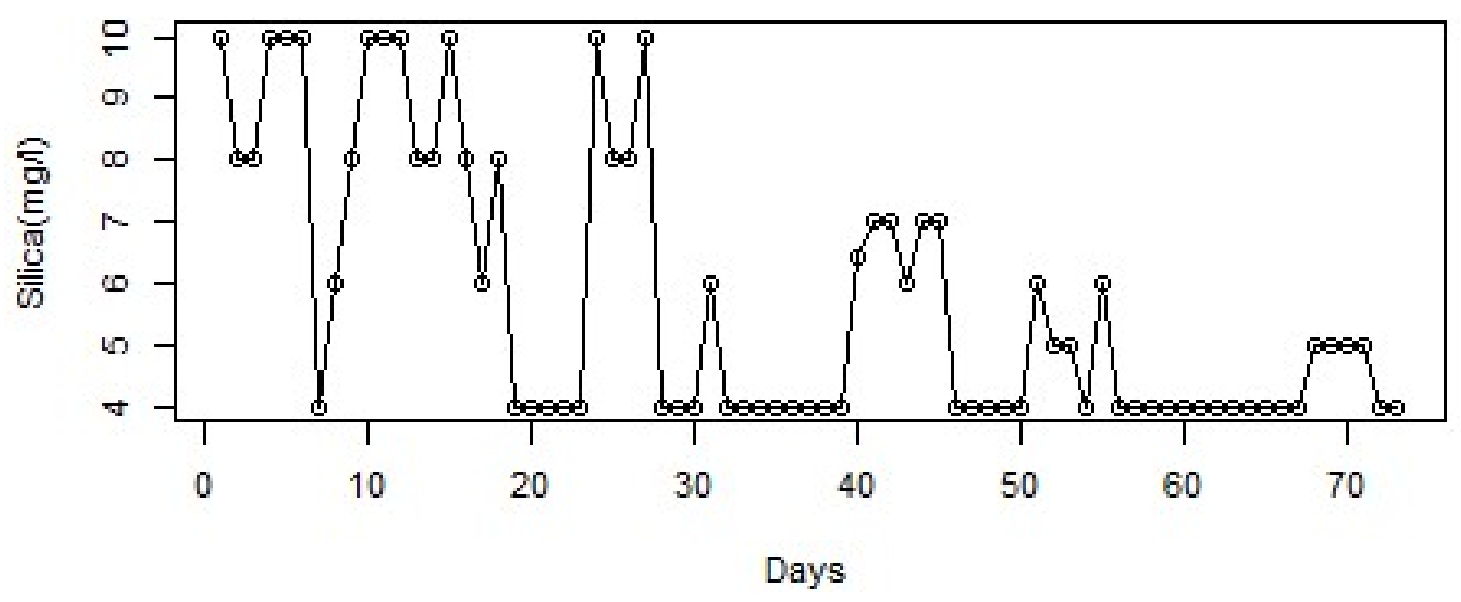

Figure 9: Daily Irregular Time plot of Silica from Eleyele Dam

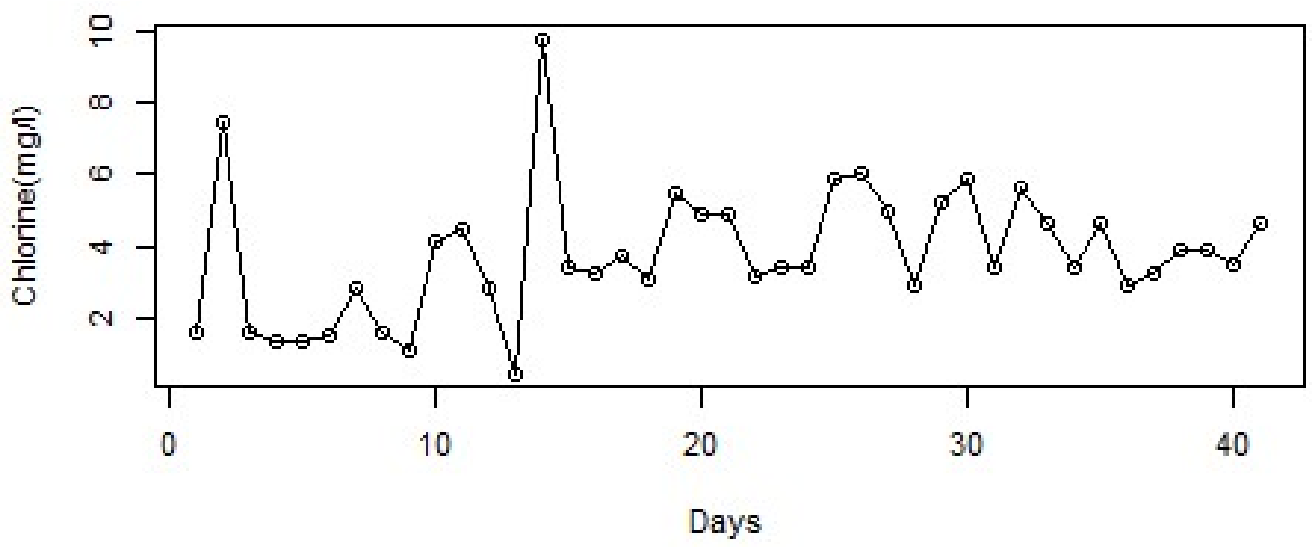

Figure 10: Daily Irregular Time plot of Chlorine from Eleyele Dam

\subsection{Conclusions}

The increasing trend in the number of patients with reported complaints of water related diseases cannot be overemphasized. The total dependence of citizens on private wells showed the gross inadequacy of public water supply (Iyun, 1994) as domestic water is often sourced from questionable alternative sources especially by those who cannot afford to sink wells. Rain is quite seasonal and often polluted by anthropogenic activities in cities that release gaseous pollutants into the atmosphere, just as unprotected well can be polluted by run-off (Enger \& Smith, 2003). Provision of potable water and water sanitation project should be adopted by government as a preventive measure to control water related diseases. Public health education of the citizens on drink safe water should be embraced. Household effective and sustainable water treatment methods such as boiling, filtering, hygienic storing and handling should be encouraged to reduce water related diseases.

\section{Acknowledgements}

This study was supported by a grant from Tertiary Education Trust Fund (TETFund) through Institution Based Research Committee (IBRC), The Polytechnic Ibadan, Nigeria.

\section{References}

Adefemi, O.S., Asaolu, S.S., Olaofe, O. (2007). Assessment of the physicochemical Status of water samples from Major Dams in Ekiti State, Nigeria. Pakistan J. Nutr. 6, 657-659.

Admasu M., Kumie A. and Fentahun M. (2003). Sustainability of Drinking Water Supply Projects in Rural of North Gondar, Ethiopia, Ethiopian. J. Health Dev. (3):221-229.

African Development Fund (ADF) (2005). Ethiopian rural water supply and sanitation appraisal report. Infrastructure department north, east and south Onin.

Crow B. (2001). Water: gender and material inequalities in the global south. University of California, 
Santa Cruz.

Enger, E.D. \& Smith, B.F. (2003). Environmental Science: A Study of Interrelationships (8 ${ }^{\text {th }}$ ed.) McGraw Hill Higher Education.

Environmental Protection Agency (2001). Parameters of Water Quality, Interpretation and Standard.

Ewa, E.E., Iwara, A.I., Adeyemi, J.A., Eja, E.I., Ajake, A.O., Otu, C.A., (2011). Impact of industrial activities on water quality of omoku creek. Sacha J. Environ. Stud. 1 (2), 8-16.

Gadgil A (1998) Drinking water in developing countries. Annu. Rev. Energ Environ. 23: 253-286.

Harman, W.N., Berg, C.O., (1971). The freshwater Gastropoda of central New York with illustrated keys to the genera and species. Cornell Univ. Agric. Exp. Station 1, 1-68.

Hussein, M.A., Obuid-Allah, A.H., Mahmoud, A.A., Fangary, H.M., (2011). Population dynamics of freshwater snails (Mollusca: Gastropoda) at Qena Governorate, Upper Egypt. Egypt. Acad. J. Biol. Sci. 3 (1), 11-22.

Hyeladi, A., Nwagilari, J.E., (2014). Assessment of drinking water quality of Alau Dam Maiduguri, Borno State, Nigeria. Int. J. Sci. Res. Publ. 4 (10), 1-6.

Yun, B.F. (1994). Health problems in Ibadan Region. In: M.O. Filani, F.O. Akintola and C.O. Ikporukpo (eds.) Ibadan Region. Rex Charles Publishers. Ibadan 256 - 261

Jordan, P., Webbe, G., (1982). Schistosomiasis: Epidemiology, Treatment, and Control. Heinemann Publication. William Heinemann Medical Books Ltd, London, pp. 300-361.

Mathew, B. (2005). IRC International Water and Sanitation Centre - Occasional Paper Series 40.

Meseret, B.A. (2012). Assessment of Drinking Water Quality and Determinants of Household Portable Water Consumption in Simada District, Ethiopia. Master's thesis, Professional Studies, Cornell University, Ithaca, USA.

Oloyede, O.O., Otarigho B., Morenikeji O., (2016). Conditions of Eleyele dam in Ibadan Nigeria inhabited by Melanoides tuberculate. Sustain. Water Qual. Ecol, http://dx.doi.org/10.1016/j.swaqe.2016.02.001

Owojori, O.J., Asaolu, S.O., Ofoezie, I.E., 2006. Ecology of freshwater snails in Opa Reservoir and research from ponds at Obafemi Awolowo University Ile- Ife, Nigeria. J. Appl. Sci. 6 (15), 30043015 .

Oyakhilome, G.I., Aiyesanmi, A.F., Akharaiyi, F.C., (2012). Water quality assessment of the Owena Multipurpose dam, Ondo State, Southwestern Nigeria. J. Environ. Protect. 3 (1), 14-25.

Masironi, R., Miesch, A.T., Crawford, M.D., Hamilton, E.I. (1972). Geochemical environments, trace elements, and cardiovascular diseases. Bull. World Health Organ. 47: 139-150

Rose, A.D. (2009). Domestic water supply an evaluation of the impacts challenges and prospect on women in rural house hold, Uganda. LUMES, Lund University.

Sharma, K.K., Sharma, S.P., Sawhney, N., (2013). Distribution and ecology of some fresh water molluscs of the Jammu division of J\&k state. J. Environ. Biol. Sci. 23 (2), 179-181.

United Nations Development Program (2006). In Timor-Leste Human Development Report 2005 United Nations Development Programme, Dili.

United Nations Children"es Fund (UNICEF) (2010). Progress on sanitation and drinking water. New York: UNICEF.

World Health Organization (2000). Disinfectants and disinfectant by products. (Environmental health criteria 216). Geneva: world health organization.

World Health Organization (2017). Guidelines for Drinking-water Quality, World Health Organization, Geneva.

World Health Organisation (2006) In Water, Sanitation and Health World Health Organisation.

Yirenya-Tawiah, D.R., Abdul Rashid, A., Futagbi, G., Aboagye, I., Dade, M., (2011). Prevalence of Snail Vectors of Schistosomiasis in the Kpong Head Pond, Ghana. West Afr. J. Appl. Ecol. 18,39. 